\title{
Optimization of the Use of Wireless Lan Devices to Minimize Operational Costs
}

\author{
Achmad Rian Tarmizi ${ }^{1}$, Ahmat Adil ${ }^{2}$, Lilik Widyawati ${ }^{3}$ \\ 1,2,3 computer science, Universitas Bumigora \\ E-Mail:achmadrian044@gmail.com ${ }^{1}$, ahmat.adil@universitasbumigora.ac.id ${ }^{2}$, \\ lilikwidya@universitasbumigora.ac.id ${ }^{3}$.
}

\begin{abstract}
WLAN technology has been widely developed for the needs of internet access in people's lives. Several generations of WLAN technology include IEEE 802.11b, IEEE 802.11a, IEEE 802.11 g and IEEE 802.11n. At the STAHN Rectorate Building, Gde Pudja Mataram, WLAN technology in its application requires financial consideration because excessive use of Internet Service Provider services results in a waste of operational costs. The application of WLAN is still not optimal, because there are not too many users, but the operational costs of implementing the local wireless network are very large, due to less optimal application of network infrastructure. The recommended WLAN technology is IEEE 802.11n, while the technology is the latest technology that has better quality than the previous generation technology. The research methodology uses the Network Development Life Cycle (NDLC). Of the 6 stages available, only 3 stages are used, namely Analysis, Design and Simulation of Prototyping. The results obtained from this study are models that design a WLAN that suits your needs, and complements the entire Building area. Optimization has succeeded in reducing the need for ISP and client services while still being able to enjoy services as needed and cost optimization can be reduced by around $28 \%$.
\end{abstract}

Keyword : Wireless LAN, Optimation, Operational Cost

Author Korespondensi (Achmad Rian Tarmizi)

Email : achmadrian044@gmail.co

\section{INTRODUCTION}

Nowadays, information technology continues to develop along with the needs of people who want the easiness, speed and accuracy in obtaining information. Therefore, the quality and quantity of advances in information technology must be continued to be pursued and improved [1]. One of the advances in information technology is computer networks. A computer network is a group of computers which can be interconnected with one another by using communication media, in order to be able to share data, information, programs, and hardware (printers, hard disks, webcams, etc.) [2] . There are several technologies used to communicate and transmit data in computer networks, one of the advances in the data transmission's field at this moment is the use of Wireless LAN [3] . Wireless LAN or WLAN is a communication system which uses air as the transmission media. WLAN uses radio frequency technology as a data storage medium and has various conveniences for users in its application [4]. In general, the application of WLAN or computer networks, certainly, needed maximum infrastructure and equipment so as not as an obstacle in the process of smooth information systems, without exception in college institutions. Therefore, it is a needed for good maintenance and optimization of the parts of the network infrastructure that are considered problematic. A good application of Wireless LAN cannot be separated from the values of the non-technical aspects, such as the aspect of the minimal operational costs and it would be detrimental to users.

\subsection{Wireless Access point}

Wireless access point (WAP) is a network device that connects network devices which lead to a wireless network or those from a wireless network. This device has function as a hub or switch on of the wireless or wireless networks, and can be used as a router which bridge the different networks like connecting a local network with an Internet Service Provider [4]. 


\subsection{OSI (Open System Interconnection)}

The OSI Reference Model for open networking or the OSI open network reference model is a network architectural model which developed by the International Organization for Standardization (ISO) in Europe in 1977 (Sofana 2008). OSI itself stands for Open System Interconnection. This model is also called the OSI seven-layer model. The OSI model was created to overcome various internetworking constraints due to differences in architecture and network protocols

WLAN is applied in the STAHN rectorate building of Gde Pudja Mataram to provide access to internet services for all staff, but the application of that WLAN is still not optimal, because with not too many users, the operational costs of implementing the local Wireless network are very high. This is due to less optimal application of the infrastructure, here one of the problems is the application of devices that are not in accordance with needs. Based on this condition, the authors intend to optimize WLAN devices in the STAHN rectorate Building, Gde Pudja Mataram. Some commonly WLAN devices used such as routers, switches, and access points.

\section{METHODOLOGY}

The research methodology used in this optimization design is NDLC (Network Development Life Cycrle). NDLC is a method used in developing or designing infrastructure networks that enable network monitoring to find out statistics and network performance. The results of the performance analysis are taken as consideration in designing network designs, both physical network designs or logical networks [5]. From the 6 NDCL phases, this design only used 2 stages, namely analysis and design.

\subsection{Analysis}

There are several analyzes or identification about user devices, service applications, and the previous network [6].

\section{User devices identification}

The use of the device as a client by rectorate building staff in the operational process mostly in the form of notebooks which are categorized by Aerohive's handbook as a low-end Laptop with wireless device capabilities as follows [7]:
Tabel 1. Low-end Laptop specification [7]

\begin{tabular}{|c|c|}
\hline $\begin{array}{c}\text { Element } \\
\text { Specification }\end{array}$ & Value specifications \\
\hline Wifi Radio Type & $802.11 \mathrm{n} 2 \times 2: 2$ \\
\hline Channel Support & $1-11$ \\
\hline Channel Width & $20 \mathrm{MHz}$ Only \\
\hline $\begin{array}{c}\text { Transmit Power } \\
\text { Output }\end{array}$ & $17-20 \mathrm{dBm}$ \\
\hline Maximum Data Rate & $144 \mathrm{Mbps}$ \\
\hline
\end{tabular}

\section{Service application identification}

In general, the staffs in rectorate building STAHN Gde Pudja are the staffs who handle administrative issues at. Here is a list of application requirements used:

Tabel 2. Service Application Identification

\begin{tabular}{|c|c|c|c|}
\hline Activites & $\begin{array}{c}\text { Throughput } \\
\text { bandwith } \\
\text { (kbps) }\end{array}$ & Internet & Intranet \\
\hline Messages/IM & $<1$ & $\checkmark$ & $\checkmark$ \\
\hline web & $50-100$ & $\checkmark$ & \\
\hline $\begin{array}{c}\text { Streaming } \\
\text { video }\end{array}$ & $64-200$ & $\checkmark$ & \\
\hline $\begin{array}{c}\text { Streaming } \\
\text { audio }\end{array}$ & $96-180$ & $\checkmark$ & $\checkmark$ \\
\hline E-Mail & $1-100$ & $\checkmark$ & $\checkmark$ \\
\hline Social Media & $64-200$ & $\checkmark$ & \\
\hline File sharing & $475-850$ & $\checkmark$ & $\checkmark$ \\
\hline
\end{tabular}

To calculate the use of application requirements VIP staff per user with a total of 44 people, in this case were fulfilled into 50 people. The estimation of per user bandwidth services can be calculated by the most bandwith activity consumed, namely 850 kbps File Sharing. Therefore, the estimated bandwidth service per user is given $850 \mathrm{Kbps}$. So that, the bandwidth requirement for 50 users is $42,500 \mathrm{Kbps}$, or 42.5 Mbps. 


\section{The previous network identification}

In this previous network identification, will be identified the use of the network devices especially to identify the issue of cost in the STAHN rectorate Building of Gde Pudja Mataram,

\section{a. Service fees}

The main problem in the Rectorate Building network is the large number of ISP service utilization which causes financial losses. There are 5 service units which utilize ISP services by rectortae building as follows:

Table 3. ISP service fees for Rectorate Building service fees

\begin{tabular}{|c|c|c|c|c|c|c|c|c|}
\hline \multirow{2}{*}{ No. } & \multirow{2}{*}{ Tellom Telpon } & \multirow{2}{*}{ Lokasi } & \multirow{2}{*}{ Speed } & \multicolumn{5}{|c|}{ Biaya $(\mathrm{Rp})}$. \\
\hline & & & & April 2019 & Mei2019 & Jumi 2019 & \begin{tabular}{|l|l|} 
\\
\end{tabular} & Agustus 2019 \\
\hline 1. & $\begin{array}{l}172601208945 \\
/(0370) 624132\end{array}$ & Umum & 100Mbps & 1.391.910 & 1.391.910 & 1.393 .395 & 1391.910 & 1.391 .910 \\
\hline 2. & $\begin{array}{l}172601802042 \\
03707504635\end{array}$ & $\begin{array}{l}\text { Pangkalan } \\
\text { Data }\end{array}$ & 20Mbps & 772.662 & 786.500 & 7855.500 & 786.500 & 786.500 \\
\hline 3. & $\begin{array}{l}172601784404 \\
103707848804\end{array}$ & Reltorat Lt. 2 & 50Mbps & & & & 2.525 .473 & 1.378 .000 \\
\hline 4. & $\begin{array}{c}172601784379 \\
103707847996\end{array}$ & Keuangan & $20 \mathrm{Mbps}$ & & & & 1.209.131 & 621.500 \\
\hline 5. & $\begin{array}{l}172601784400 \\
03707849745\end{array}$ & Alademik & 20Mbps & & & & 1.420 .157 & 742.500 \\
\hline
\end{tabular}

Based on the budget data of STAHN Gde Pudja Mataram, the budget spent for WLAN operational of the Rector's Building in last month's costs as follows:

- Monthly = Rp. 4,902,410

- Half Semester $=$ Rp. 14,707,230

- Semester $=$ Rp. 29,414,460

- Yearly $=$ Rp. 58,828,920

b. The scheme of the Previous of WLAN Utilization

The WLAN implementation scheme in the rectorate STAHN Gde Pudja Mataram uses a standard LAN network of PT. Telkom which uses the Wireless Router as an Access point that connects clients to the hotspot directly. The wireless technology used is the 802.11n standard with a frequency of $2.4 \mathrm{GHz}$. Some brands of Wireless Router that are used such as Alcatel Lucent, Nokia, and TP-Link. The WLAN utilization scheme in the previous rectorate building is as follows:

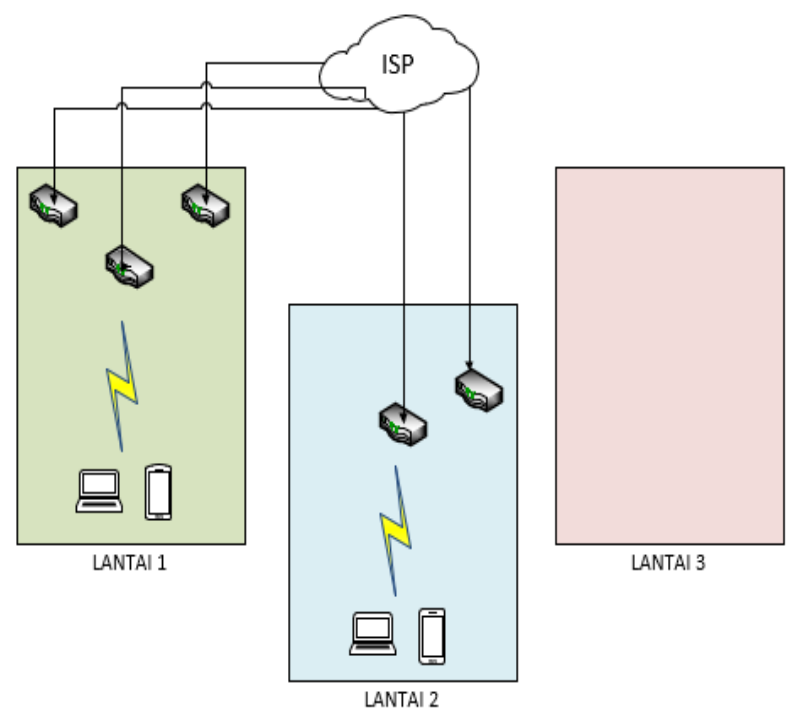

Figure 1. WLAN Scheme of the previous Rectorate

c. Rectorate building Plan and placement of equipment and signal coverage area

The Rector's Office of STAHN Gde Pudja Mataram consists of 3 floors with the width of each area of $\pm 45 \times 18 \times 4$ meters per floor. From the 5 ISP wireless router devices, 3 placed on the 1 st floor for the public, academic and financial Room and 2 wireless routers placed on the 2nd floor for the UPD and Loby Rooms. The measurement of coverage area or signal coverage area is based on the location of the maximum quality of the signal which can be reached by the Wireless Router ISP.

The measurements were made by using Wifi Network Analyzer tools. The power of the Wifi signal is indicated by $\mathrm{dBm}$ (decible milli Watt). Ii is the absolute value of the power unit, calculated as $10 \log$ power value / $1 \mathrm{~mW}$. When the shown value is greater, the strength of the signal will be smaller [8]. The Quality Standards for the Signal to Noise Ratio (SNR) quality variable in the Signal Level indicator are as in Table 6. below. 
Table 4. The Signal Quality Indicators [8]

\begin{tabular}{|c|l|l|}
\hline No & Signal Quality & $\begin{array}{c}\text { Signal Strength } \\
\text { Value (dBm) }\end{array}$ \\
\hline 1 & Very Good & $<-60 \mathrm{dBm}$ \\
\hline 2 & Good & -60 to $70 \mathrm{dBm}$ \\
\hline 3 & Fairly Bad & -71 to $80 \mathrm{dBm}$ \\
\hline 4 & Bad & -81 to $90 \mathrm{dBm}$ \\
\hline 5 & Very Bad & $-90 \mathrm{dBm}$ \\
\hline
\end{tabular}

Measurements are made for at least 2 minutes at each point and based on the extent to which the signal quality is classified as fairly bad category with the signal strength is at -71 to $-80 \mathrm{dBm}$ (decible milliWatt). The first measurement is made toward a wireless router in the public room with the results of the measurement below:

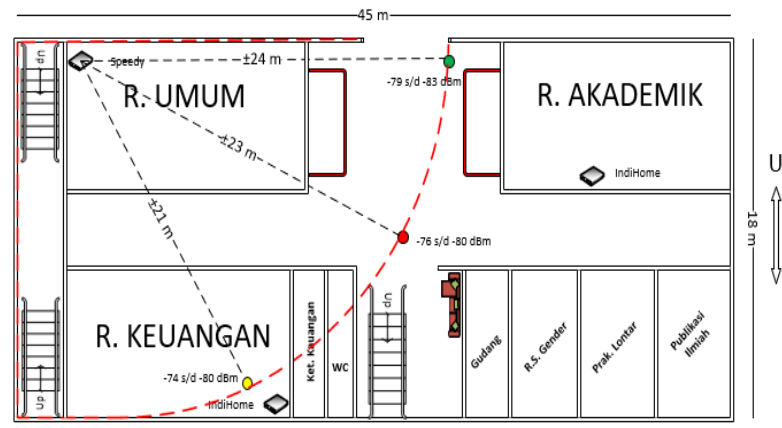

Figure 2. Coverage area of the Public Area wireless router

Wireless Router in the Public Area is measured from 3 points as shown in Figure 3 below. Measurements of the red dot are $\pm 23 \mathrm{~m}$ the with signal quality between -76 to $-80 \mathrm{dBm}$, measurements of the yellow dot are $\pm 21 \mathrm{~m}$ with the signal quality between -74 to $-80 \mathrm{dBm}$, and the measurement of the green point is $\pm 24 \mathrm{~m}$ with the signal quality between -79 to $-83 \mathrm{dBm}$.

The difference of signal quality is not only influenced by distance but also by indoor interference such as walls and doors. Assuming the coverage area of the wireless router signal is represented by a red line. The second measurement is made on the wireless router in the Financial Room with the following measurement results:

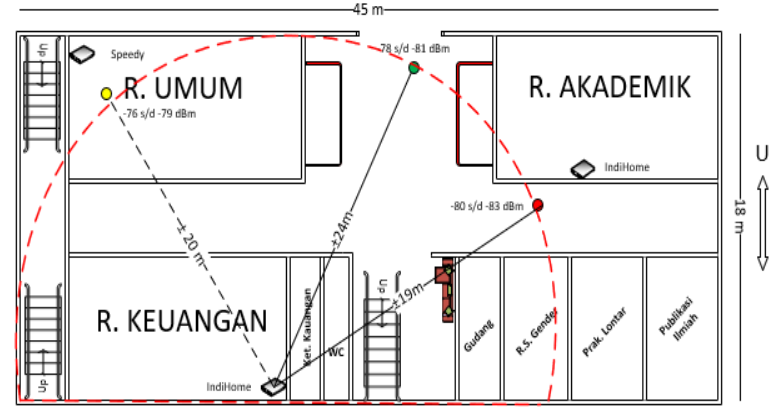

Figure 3. Coverage area of the Financial Room wireless router

The Wireless Router in the Financial Room is measured from 3 points as shown in Figure 12. The measurement at the red point is $\pm 19 \mathrm{~m}$ with the signal quality between -80 to $-83 \mathrm{dBm}$. Measurements at the yellow dot is $\pm 20 \mathrm{~m}$ with the signal quality between -76 to $-79 \mathrm{dBm}$. While the measurement at the green point is $\pm 24 \mathrm{~m}$, with the signal quality between -78 to $-81 \mathrm{dBm}$. The third measurement is made to the wireless router in the academic room with the following measurement results:

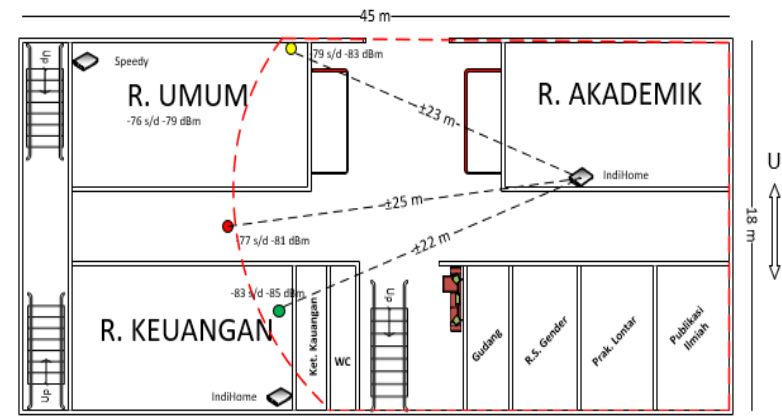

Figure 4. Coverage area of the Academic Room wireless router area

The Wireless Router in the Academic Room is measured from 3 points as shown in Figure 13. The Measurement of the red point is $\pm 25 \mathrm{~m}$ with the signal quality between -77 to $-81 \mathrm{dBm}$. The second measurement of the yellow dot is $\pm 23 \mathrm{~m}$ with the signal quality between -76 to $-83 \mathrm{dBm}$. While the third measurement of the green point is $\pm 22 \mathrm{~m}$ with signal quality between -83 to -85 $\mathrm{dBm}$. The fourth measurement is made on the wireless router in the data base unit room with the results of the measurement below: 


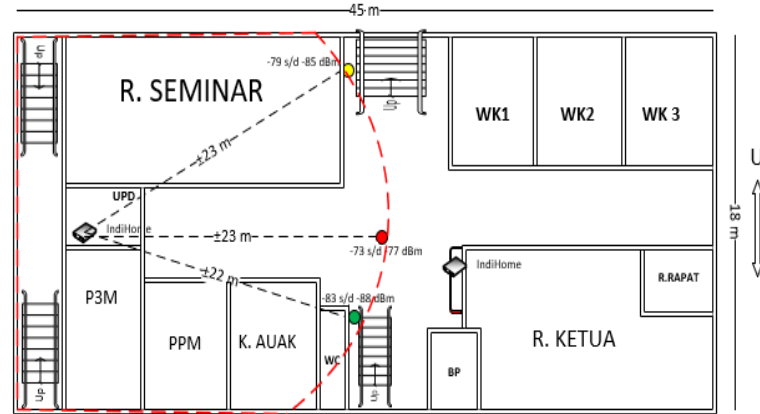

Figure 5. Coverage area of the wireless router UPD room

The Wireless Router in the UPD room is measured from 3 points as shown in Figure 14. The measurement at the red point is $\pm 23 \mathrm{~m}$ with the signal quality between -73 to $-77 \mathrm{dBm}$. Measurements at the yellow dot are $\pm 23 \mathrm{~m}$ with the signal quality between -79 to $-85 \mathrm{dBm}$. While the measurement at the green point is $\pm 22 \mathrm{~m}$ with the signal quality between -83 to $-88 \mathrm{dBm}$. The last measurement was carried out on the wireless router in the middle room loby with the the results of measurement below:

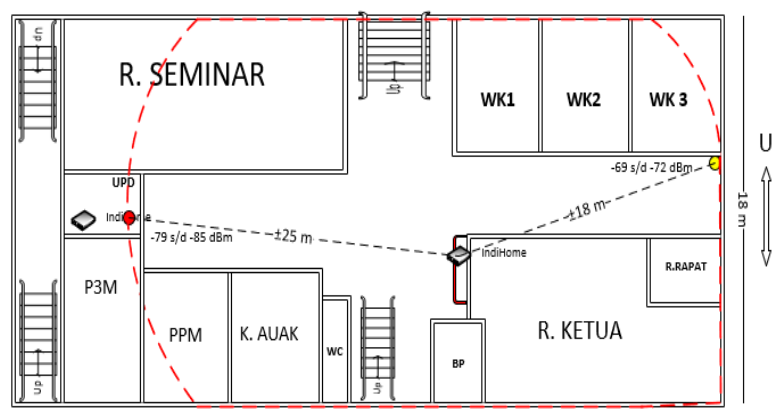

Gambar 6. Coverage area wireless router Lobby. Midle R

The Wireless Router in the Lobby room is measured from 2 points as shown in Figure 15. The measurement at the red point is $\pm 25 \mathrm{~m}$ with the signal quality between -79 to $-85 \mathrm{dBm}$. Measurements at the yellow dot is $\pm 18 \mathrm{~m}$ with the signal quality between -69 to $-72 \mathrm{dBm}$.

While on the 3rd floor, there is no WLAN device that can transmit signals, but the wireless router signal can still be reached from the UPD Room and Lobby Room Central on the 2nd floor but with very poor quality condition, which is below $-90 \mathrm{dBm}$. From the measurement results of each ISP wireless router on the 1st and 2nd floors, obtained the overall area as follows:

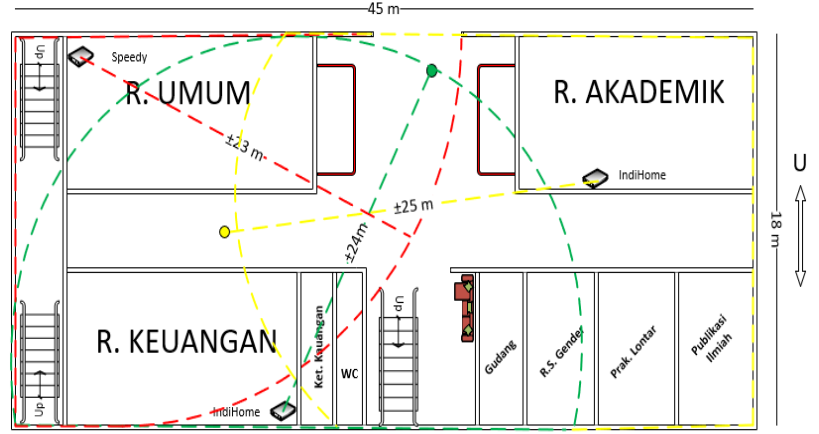

Figure 7. Overall coverage area of the 1st floor

The result on the first floor shown that the wi-fi signal can cover the entire room of the 1st floor and there is no death zone found.

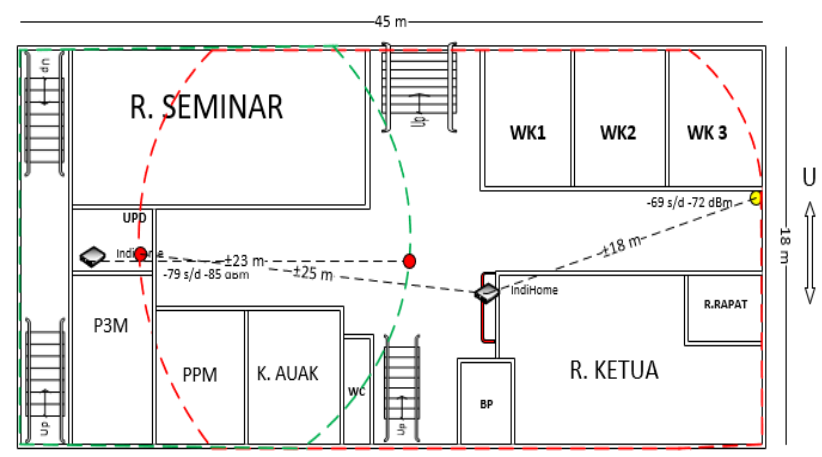

Figure 8. Overall coverage area of the 2nd floor

On the 2nd floor, the result show that, the wi-fi signal can cover most of the entire room on the 2nd floor specifically in the corner of the WK3 room, but there is a slight angle where the wi-fi signal categorized as bad category and it is While on the whole of 3rd floor is assumed as death zone because of the wi-fi signal that can be reached only with a signal quality of $-90 \mathrm{dBm}$ and it cannot access the network.

\subsection{Design}

In order to get the design, several things will be determined based on the results of the analysis such as, the needed technology will be applied, and the identification of coverage signal and environmental characteristics.

\section{A. Technology Identification Based on Need}

There are several things that need to be identified in this part, such as:

1. The Wireless network model will be used

2. The WLAN model selection will be to be utilized, and 
3. The number of devices needed to be calculated

B. Identification of Scope and Characteristics of the Environment

At this stage, the scope and characteristics of the environment are identified based on the location of the application of the WLAN which will be optimized in order to obtain supporting analysis in selecting the WLAN technology which will be used. The Environmental characteristics consist of the building area of the rectorate building and the existing of annoying interferences of wireless signal. Coverage Identification is the identification of the wireless range signal based on the capabilities of the device to be used in optimization.

\section{RESULTS AND DISCUSSION}

This section discusses the results of the recommended WLAN optimization design model started from the results of the optimization network design, the process of simulation, and the results of the budget after optimization.

\subsection{Network Design}

There are some indicators that need to be considered in optimizing this WLAN device like the technology used and the environmental characteristics of the WLAN application location.

\section{A. Technology Identification Based on Need}

The utilization of WLAN in the rectorate building is still a standard of PT. Telkom namely Wireless Router which is configured as a PPPoE Client in order to be able to receive the internet connections from PT. Telkom. It is needed external router such as proxy, tp-link, huawei, cisco, and so on when we want to do network management In this design, in order to external router can perform network management optimally, the dial up process to PPPoE Server is done through an external router. An external router here has functions as a PPPoE Client, while the Wireless Router functions as a bridge.

\section{The selection of Wireless Network Model}

WLAN has 2 types of networks that can be used, namely Ad-Hoc network and Infrastructure network types. Ad-Hoc network type is a wireless network that does not use an Access Point. While the infrastructure network type is a wireless network that requires an access point [9]. The model used in the design of this optimization is an infrastructure model. When the client want to access the network especially the internet, they must be connected to the Wireless Router ISP / Access point.

\section{The selection of WLAN Technology}

In accordance with the specifications of the user equipment and for the better access speeds, the WLAN technology that is used in the STAHN Gde Pudja Mataram Rectorate Building is IEEE $802.11 \mathrm{n}$ with a frequency of $2.4 \mathrm{GHz}$. One example of a WLAN device with the IEEE 802.11n standard with MIMO features and works at a frequency of $2.4 \mathrm{GHz}$ that can be used is the Totolink N9 access point.

\section{Calculation of access points number needed}

The amount of AP required is calculated based on airtime per device and airtime utilization. Airtime per device is the length of time of communication between the device and the AP is needed in order to the application throughput needs can be reached [7]. In this case, the throughput needs that become reference are the biggest throughput from the various application needs. Rectorate Building Staff requires the biggest throughput in the File Sharing application of $850 \mathrm{Kbps}$. Airtime per device, APD is calculated according to the formula [7]:

$$
A P D=A p p T / C D R
$$

AppT is the recommended throughput required by applications that use the network in order to be able to function normally while the client data rate, $\mathrm{CDR}$, is the maximum bandwidth of the user's device communication capabilities. Airtime utilization is the total communication time (airtime) requirement of all user devices and will be rounded up to the amount of AP required. Airtime utilization, AU, calculated according to the formula [7]:

$$
A U=A P D \times N o D
$$

NoD is the number of devices or the number of user devices. Thus the need for airtime per device based on (Equation 1) is: 
$\mathrm{APD}=0.8 \mathrm{Mbps} / 144 \mathrm{Mbps}$

$\mathrm{APD}=0.5 \%$

Assuming the worst case is that there are 50 users simultaneously doing file sharing, then the airtime utilization based on (Equation 2) has a value:

$$
\begin{aligned}
& \mathrm{AU}=0.5 \% \times 50 \\
& \mathrm{AU}=25 \%
\end{aligned}
$$

Which means that, if an AP has $100 \%$ airtime, then $0.4 \mathrm{AP}$ are needed to meet the needs of $25 \%$ airtime utilization. Often practically, AP only can use $80 \%$ of its airtime under conditions of solid use so that airtime utilization under realistic conditions, RAU, is:

$$
\begin{aligned}
& \text { RAU }=25 \% / 80 \% \\
& \text { RAU }=0,3 \%
\end{aligned}
$$

meaning that it needs 0,3 units or fulfilled 1 AP for the needs of 50 users in one point simultaneously.

Each APUT will be connected to a router that is connected to the ISP Wireless Router. If each AP serves about 15 to 20 users with application throughput at $0.8 \mathrm{Mbps}$ then the aggregate throughput is $9.6 \mathrm{Mbps}$ to $16 \mathrm{Mbps}$. So, a WLAN connection with a bandwidth of 20 Mbps is sufficient on 1 point of access point with 10-20 users. If you need a throughput of 850 Kbps / $0.8 \mathrm{Mbps}$, so 50 connections will require bandwidth of 42.5 Mbps. If you need a bandwidth of $42.5 \mathrm{Mbps}$, ISP services that can be utilized are $50 \mathrm{Mbps}$. However, to reduce risks such as when many visitors in the Rectorate Building such as events in the hall, the ISP service that can be utilized is $100 \mathrm{Mbps}$.

\section{Frequency Channel Selection}

With limited wireless communication capabilities of user devices that can only work in the $2.4 \mathrm{GHz}$ frequency with the $802.11 \mathrm{n}$ standard, the frequency band used is $2.4 \mathrm{GHz}$. Channel width is adjusted by user devices that only support $20 \mathrm{MHz}$ channel width. In the $2.4 \mathrm{GHz}$ frequency band there are only 11 channels while only 3 channels can be used close together. The division of channels at the $2.4 \mathrm{GHz}$ frequency as shown in Figure 8 below.

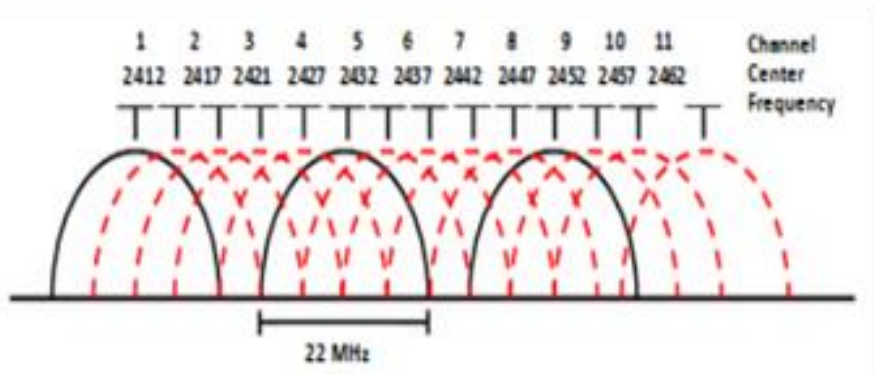

Figure 9. Distribution of $2.4 \mathrm{GHz}$ Frequency Band Channels [10]

Using improper frequency channels will cause interference because the frequencies used are overlapping. Therefore, in order to avoid interference, it must use non-overlapping channels with the formula " $+5 \&-5$ ", i.e. $1,6,11$ on a different Wireless Access point network.

B. Identification of Scope and Characteristics of the Environment

Some important factors that also need to be known in designing this WLAN optimization model are the characteristics of the study location environment, as well as the coverage area that can be reached by the WLAN device used.

1. Environmental Characteristics

The Rector's Building has three floors covering \pm $45 \mathrm{mx} \pm 18 \mathrm{~m}$, and the floor height is \pm 4 meters, on the first floor there are nine rooms, the three largest rooms have a length of \pm 15 -17 meters with a width of \pm 7 meters, while other are smaller room, the second floor has twelve rooms and the third floor has only one hall room. Each room is separated by a partition in the form of a \pm $12 \mathrm{~cm}$ brick wall and $\mathrm{a} \pm 3 \mathrm{~cm}$ thick wooden door.

\section{Identification of Scope}

Amanaf et al. (2018) in his research provided a comparison of the range among Wi-fi technologies, namely 802.11a, 802.11b, 802.11g, and $802.11 \mathrm{n}$ with a comparison as follows.

Table. 5 the comparison of Wi-fi Technology [11]

\begin{tabular}{|l|l|l|l|l|}
\hline $\begin{array}{l}\text { Protoco } \\
\text { I }\end{array}$ & $\begin{array}{l}\mathbf{8 0 2 . 1} \\
\mathbf{1 a}\end{array}$ & $\begin{array}{l}\mathbf{8 0 2 . 1 1} \\
\mathbf{b}\end{array}$ & $\begin{array}{l}\mathbf{8 0 2 . 1} \\
\mathbf{1 g}\end{array}$ & $\begin{array}{l}\mathbf{8 0 2 . 1 1} \\
\mathbf{n}\end{array}$ \\
\hline Rilis & 1999 & 1999 & 2003 & 2009 \\
\hline $\begin{array}{l}\text { Frequen } \\
\text { cy }\end{array}$ & $5 \mathrm{Ghz}$ & $\begin{array}{l}2,4 \\
\text { Mbps }\end{array}$ & $\begin{array}{l}2,4 \\
\text { Mbps }\end{array}$ & $\begin{array}{l}2,4 \\
\text { Mbps }\end{array}$ \\
\hline
\end{tabular}




\begin{tabular}{|l|l|l|l|l|}
\hline $\begin{array}{l}\text { Operatio } \\
\mathrm{n}\end{array}$ & & & & \\
\hline $\begin{array}{l}\text { General } \\
\text { Throug } \\
\text { put }\end{array}$ & $\begin{array}{c}23 \\
\text { Mbps }\end{array}$ & $\begin{array}{l}4,3 \\
\text { Mbps }\end{array}$ & $\begin{array}{l}19 \\
\text { Mbps }\end{array}$ & $\begin{array}{l}74 \\
\text { Mbps }\end{array}$ \\
\hline $\begin{array}{l}\text { Data } \\
\text { Rate } \\
\text { Maksim } \\
\text { um }\end{array}$ & $\begin{array}{c}54 \\
\text { Mbps }\end{array}$ & $\begin{array}{l}11 \\
\text { Mbps }\end{array}$ & $\begin{array}{l}54 \\
\text { Mbps }\end{array}$ & $\begin{array}{l}248 \\
\text { Mbps }\end{array}$ \\
\hline $\begin{array}{l}\text { Modula } \\
\text { tion }\end{array}$ & OFD & DSSS & $\begin{array}{l}\text { OFD } \\
\text { M }\end{array}$ & MMO \\
\hline $\begin{array}{l}\text { Indoor } \\
\text { Range }\end{array}$ & $35 \mathrm{~m}$ & $38 \mathrm{~m}$ & $38 \mathrm{~m}$ & $70 \mathrm{~m}$ \\
\hline $\begin{array}{l}\text { outdoor } \\
\text { Range }\end{array}$ & 120 & $140 \mathrm{~m}$ & $140 \mathrm{~m}$ & $250 \mathrm{~m}$ \\
\hline $\begin{array}{l}\text { Capabil } \\
\text { ities }\end{array}$ & $\mathrm{a}$ & $\mathrm{b}$ & $\mathrm{b} . \mathrm{g}$ & b.g.n \\
\hline
\end{tabular}

Because it uses $802.11 \mathrm{n}$ technology, it can be seen in the table above, the indoor range that can be reached as far as $70 \mathrm{~m}$ if in a room without barriers, and then it can be assumed with a building area of $45 \times 18 \mathrm{~m}$ per floor, with 3 floors, each floor can be placed with 1 access point. However, in reality, inside the building itself, there are also many barriers that will provide interference, so if the signal coverage area of $802.11 \mathrm{n}$ is $70 \mathrm{~m}$ without a barrier in the room, then with the additional interference from the insulation or walls in the room, the range can be calculated $(1 / 2 \times 70)=35 \mathrm{~m}$ per Access point. Based on the measurement results of the Coverage area of the network that was previously applied, the signal from the Wireless Router from ISP with IEEE $802.11 \mathrm{n}$ technology that works at $2.4 \mathrm{GHz}$ frequency, does not optimally distribute signals between floors in the Rectorate Building, as the signal equipment on the 1st floor does not reach the floor 2. For that reason, with the characteristics of the STAHN Gde Pudja Mataram Rectorate Building which has three floors, a different access point is needed on each floor. So, with a room area of $45 \times 18$ meters, if the estimated reach per access point is 35 meters, each insulated floor requires 2 access points, and floors that do not have a bulkhead require 1 access point. From the results of technology identification based on needs and Identification of Characteristics and environmental coverage, then by estimating the needs of five Access Points, by dividing 2 access points on the 1st floor, 2 access points on the 2 nd floor, and 1 access point on the 3rd floor, the WLAN optimization design scheme The Rector's Building is as follows.

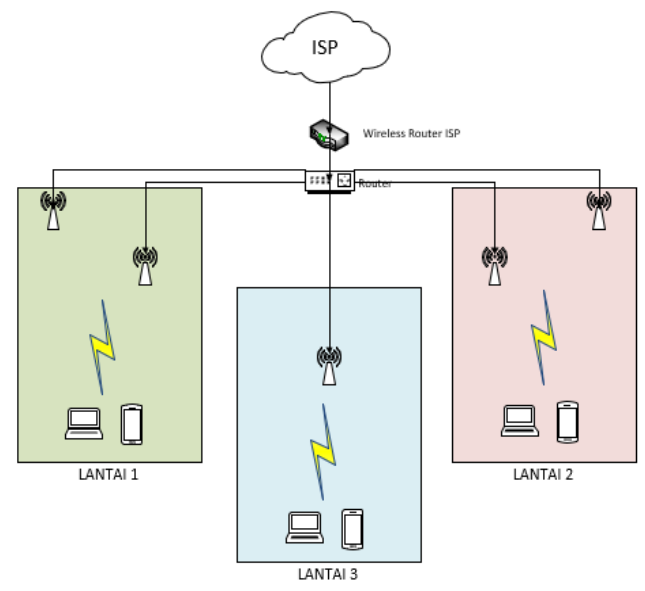

Figure 10. Optimization Network Scheme

The results of the design of the placement of the device along with the respective coverage area using vision on each floor are as follows.

a. 1 st floor

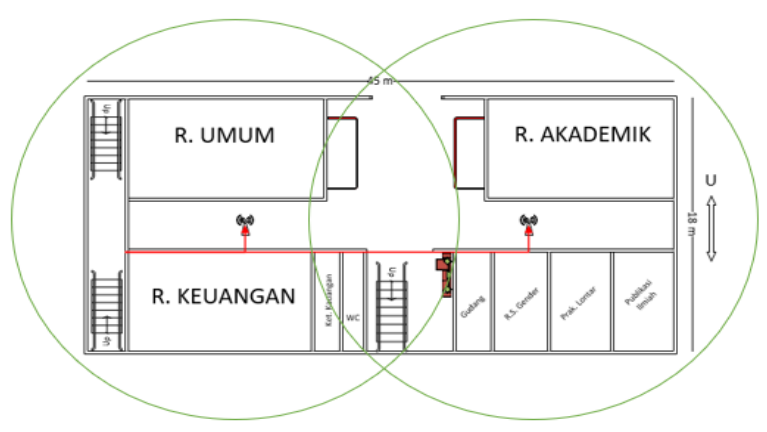

Figure 11. Coverage area on the 1st floor

On the 1st floor, placement of 2 access points assuming 35 meters of signal coverage, placed at a distance between devices is 22 meters in order to get the midpoint, with an overview of the coverage area as Figure 11 above.

The red line is a LAN cable that is connected to each access point through an external router in the 2 nd floor of the UPD Room. 


\section{b. 2nd Floor}

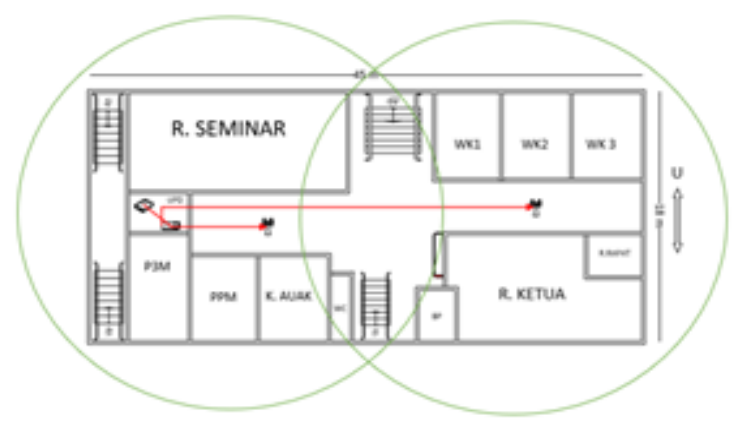

Figure 12. Coverage area on the 2 nd floor

On the second floor, placement of 2 access points assuming 35 meters signal coverage, placed at a distance between devices that is 22 meters in order to get a midpoint, then wireless routers from ISPs and external routers are also placed in the UPD Room for easy management, with an overview of the coverage area like Figure 12 above.

\section{c. 3rd floor}

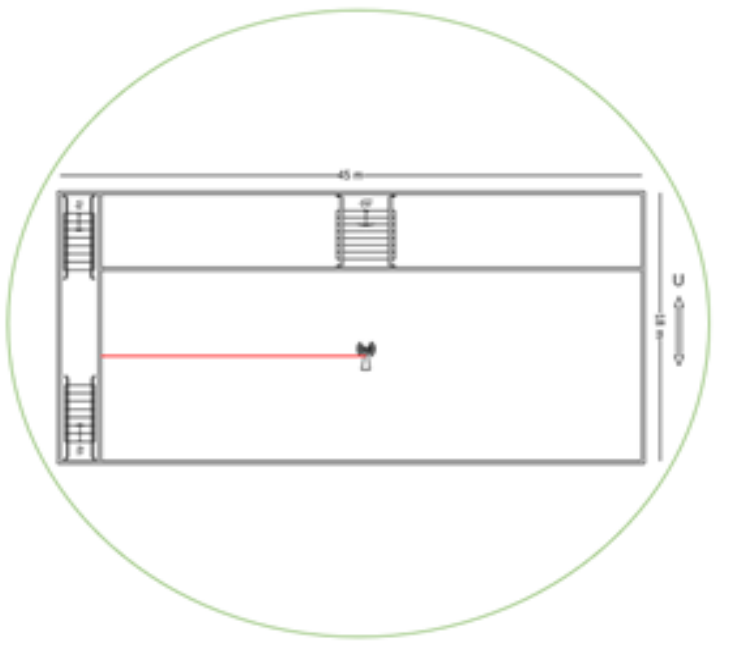

Figure 13. Coverage area on the 3rd floor

On the 3rd floor, because it is a large room namely the Hall, the placement of the access point device with assume 70 meter signal coverage is placed in the middle of the Hall's room, with the coverage area as shown in Figure 13 above.

With this optimization design model, the distributed wi-fi signal will reach every corner of the Rector's Building and there will be no death zone.

\subsection{Simulation}

This stage is carried out to simulate the use of the required WLAN device, and provide an overview of how the network works recommended based on the results of the study. The initial stage of the simulation is to input the device according to the design requirements of the Cisco packet tracer and a topology is made. Based on the results of the identification of technological requirements, the devices needed include routers, access points, and laptops / notebooks

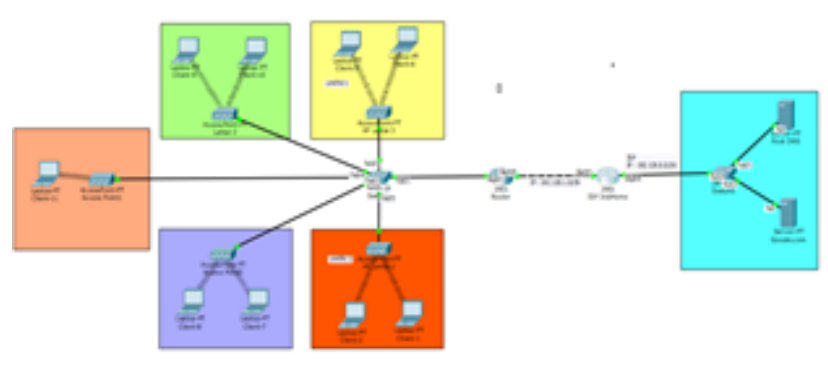

Figure 14. Inputting device and topology

In the topology above, a switch is added if the external router used to manage the network has a few ports. The placement of 5 access points is represented by 5 different color areas. Configuration is performed on an external router to provide DHCP IPs to clients that are routed through the access point. It also configured NAT Overload so that existing clients can connect to the internet using 1 IP address, while the router from the ISP is configured to be bridge mode. And after configuring, then try the connections of all clients connected to the access point to the ISP router using a simple PDU.

The testing parameter is whether the network design model as recommended can run as expected or vice versa. The trial results are as follows: 


\begin{tabular}{|c|c|c|c|c|c|c|}
\hline \multicolumn{7}{|l|}{ poulie líndon } \\
\hline fin Las Sats & Surte Desseation & Thpe Color & $\operatorname{Ten}(s e c) \mathrm{Pe}$ & rodoc & $\mathrm{Nan}$ & sit Dete \\
\hline - Sucesstul & Clert.1 159 inditome & 109 & 0,000 & $N$ & 0 & $(\operatorname{set} t)$ \\
\hline - Sucesstul & Cient-2 15P inohume & $10 \%$ & 0000 & N & 1 & (etst) \\
\hline - Successid & Oent? IS inolitumt & $10 \%$ & 0,000 & N & 2 & (tet) \\
\hline - Suctassfil & Cietts $15 \mathrm{P}$ toditume & top & 00000 & N & 3 & (ett) \\
\hline - Suntesstul & Cient-6 19 inditure & 109 & 0000 & N & 4 & (ent) \\
\hline - Sucesstil & Oet.5 15 indihume & top & 0000 & N & 5 & (est) \\
\hline e Successil & Olert-159 inohume & tove & 00000 & N & 6 & (eski) \\
\hline e Suctesstil & Chet's ISPIsthome & 100 & 00000 & N & 7 & (stit) \\
\hline - Successtul & 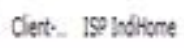 & top & 0000 & N & 8 & (est) \\
\hline
\end{tabular}

Figure 15. The results of ping from the client to the ISP router

It appears that from all clients connected to the access point successfully connected to the ISP router, this means that the client can connect to the ISP network. Then to prove whether the client can access the internet, will be tested to access google.com on an internet server, with the following results:

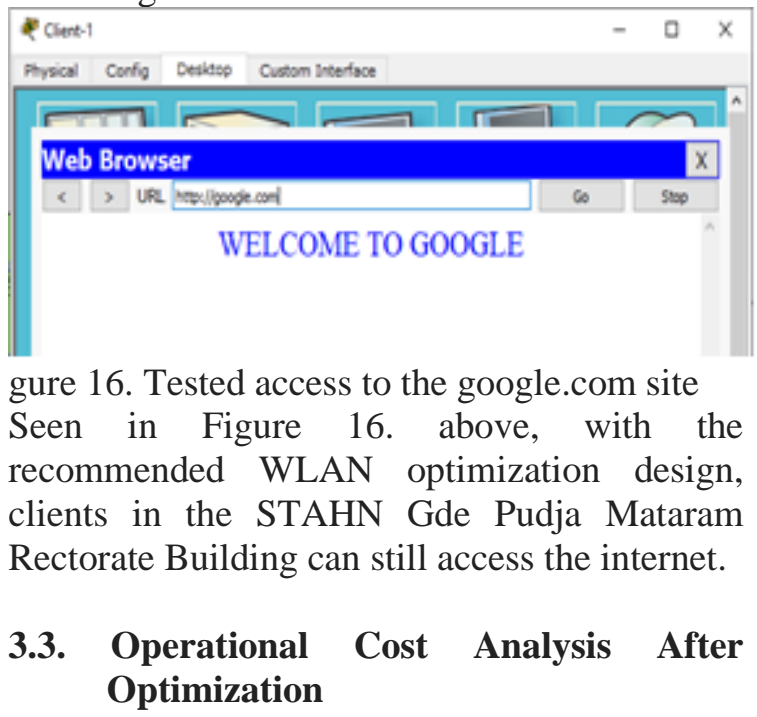

Calculation of operational cost analysis after optimization is calculated from the needs of the first month, where, in the first month the budget is calculated based on service costs and the cost of procuring new equipment.

The first point is about Internet Servive Provider services, based on the calculation of service application needs, where the recommended bandwidth requirement is $100 \mathrm{Mbps}$. So, from 5 ISP services from vendor PT. Telkom Indonesia, which was previously used, will be stopped by 4 other services with a bandwidth of $50 \mathrm{Mbps}, 20$ Mbps, $20 \mathrm{Mbps}$, and $20 \mathrm{Mbps}$. The use of 100 Mbps service on the previous network has a monthly fee of Rp. 1,391,000. The second point is about the need for an external router device, using the Mikrotik Routerboard RB2011iLS-IN router that is in the Database Unit Room and is not utilized. So there is no budget for external router costs. Mikrotik Routerboard RB2011iLSIN has 10 ports and can meet the needs of the port to connect 5 access points with the router. The third point, where the procurement of new devices in this optimization model requires an access point to spread the wi-fi signal to clients who use 5 Totolink N9 access points at a price of Rp. 610,000. Then the total budget requirement for access point costs is Rp. 3,050,000. The budget for the access point itself only applies to procurement in the first month and does not need a budget for the following months.

So, the budgeting needs of several points for optimizing the device, the budget for the first half semester calculation is obtained as in Table 6 below.

Table 6. Budget after optimization

\begin{tabular}{|c|c|c|c|c|c|c|}
\hline \multirow{2}{*}{ o } & \multirow{2}{*}{$\begin{array}{l}\text { Materi } \\
\text { al }\end{array}$} & \multirow{2}{*}{$\begin{array}{l}\text { Units } \\
\text { Price }\end{array}$} & \multicolumn{3}{|c|}{ Monthly Budgeting (Rp) } & \multirow[b]{2}{*}{ Total } \\
\hline & & & Month 1 & Month 2 & $\begin{array}{l}\text { Month } \\
3\end{array}$ & \\
\hline & $\begin{array}{l}\text { ISP } \\
\text { Service } \\
\mathrm{s}\end{array}$ & $\begin{array}{l}1.391 .00 \\
0\end{array}$ & 1.391 .000 & $\begin{array}{l}1.391 .00 \\
0\end{array}$ & $\begin{array}{l}1.391 .0 \\
00\end{array}$ & $\begin{array}{l}4.173 . \\
000\end{array}$ \\
\hline & Router & - & - & - & - & - \\
\hline & $\begin{array}{l}\text { Acces } \\
\text { Point }\end{array}$ & 610.000 & 3.050 .000 & - & - & $\begin{array}{l}3.050 . \\
000\end{array}$ \\
\hline \multicolumn{3}{|c|}{ Total (Rp) } & 4.441 .000 & $\begin{array}{l}1.391 .00 \\
0\end{array}$ & $\begin{array}{l}1.391 .0 \\
00\end{array}$ & $\begin{array}{l}7.223 . \\
000\end{array}$ \\
\hline
\end{tabular}

In the first month, the total budget cost is calculated based on ISP service costs and procurement of 5 access points, which is Rp. $4,441,000$. For the following month, the budget is only based on ISP service costs, because after the first month there will be no more cost for accessing the device. So, if the estimated operational costs of implementing WLAN in the Rectorate Building for half a semester of ISP service payments is Rp. 4,173,000. The fee for one semester is Rp. 8,345,000. and the annual service fee is Rp. 16,692,000. With an annual cost of Rp. 16,692,000, the service budget for the Rectorate Building is Rp. 333,840 / staff. And for the monthly budget, the STAHN Gde Pudja 
Mataram only needs to spend a budget of Rp. 27,820 / staff. When compared with the annual cost with the application of the previous WLAN network at a cost of Rp. 58,828,920, then STAHN Gde Pudja Mataram can save budget costs of Rp. 42,137,920.

But often in its application, it is not uncommon for down time on an ISP service. If this happens when the staff is doing important work and requires an internet connection, such as when downloading and uploading important documents and is very urgent, of course the down time problem can be a serious problem. To minimize the risk of down time, then a backup ISP service is needed and a load balancing system is implemented, where if the service of the main ISP goes down, it will be immediately taken over by the backup ISP service. With the design model previously described which is only enough with 1 ISP, then to backup ISP services it is also sufficient to utilize 1 service, so that the ISP services needed to implement load balancing are 2 services, for example the main ISP service uses IndiHome services from PT. Telkom, while the backup ISP service uses GIG services from Indosat Ooredoo, where indeed at present, only the two providers are able to reach the NTB region. If it is assumed at the backup ISP, which is Indosat $50 \mathrm{Mbps}$, then this bandwidth has been able to meet the needs of $42.5 \mathrm{Mbps}$ bandwidth requirements for the entire Rectorate Building.

Based on the official GIG Indosat website, gig.id [10], the price of $50 \mathrm{Mbps}$ data service is Rp. 499,000 / month. So if you apply a load balancing system with Indihome services from PT. Telkom at 100 Mbps and Indosat GIG from Indosat Ooredoo at $50 \mathrm{Mbps}$. So, in the first month, the total budget cost is calculated based on the cost of 2 ISP services and the procurement of 5 access points with a total cost of 2 ISPs, namely Rp. 1,391,000 + Rp. $499000=\mathrm{Rp}$. $4,940,000$. For the following month, the budget is only based on ISP service costs, because after the first month there are no more costs for procuring access point devices. So, if the estimated operational costs of implementing WLAN in the Rectorate Building for half a semester of ISP service payments is $\mathrm{Rp}$. 4,173,000 + Rp. $1,497,000$ which is Rp. 5,670,000. The fee for one semester is Rp. 11,340,000. and the annual service fee is Rp. 22,680,000. With an annual cost of Rp.22,680,000, the staff service budget at the Rector's Building is Rp. 22,680,000 / $50=$
Rp. 453,600 / staff. And for the monthly budget, the STAHN Gde Pudja Mataram only needs to spend a budget of Rp. 37,800 / staff. When compared with the annual cost with the application of the previous WLAN network at a cost of Rp. 58,828,920, then STAHN Gde Pudja Mataram can save budget costs of Rp. $36,148,920$ with the application of load balancing from 2 ISP services.

\section{CONCLUSION AND SUGGESTIONS}

Based on the results of research that has been done, it can be concluded that:

1. Based on the results of the analysis that peruser bandwidth requirement by the rector staff is $850 \mathrm{Kbps}$, and $42.5 \mathrm{Mbps}$ for the estimated bandwidth requirements of all staff.

2. The optimization model for WLAN design is successfully suppresses the need for ISP services and clients can still enjoy services as needed.

3. Budgeting based on the optimization model when it compared to previous network can be reduced around $72 \%$

4. Budgeting based on the optimization by applying load balancing system if it is compare to previous network can be reduced around $65 \%$.

\section{ACKNOWLEDMENT}

By the completion of this research, the author would like to thank for those who have helped a lot in completing this research. On this occasion the authors convey their thanks to: Supervisors and Leaders of STAHN GDE PUDJA Mataram.

\section{REFERENCE}

[1] R. Choirudin and A. Adil, "Implementasi Rest Api Web Service dalam Membangun Aplikasi Multiplatform untuk Usaha Jasa," MATRIK J. Manajemen, Tek. Inform. dan Rekayasa Komput., vol. 18, no. 2, pp. 284-293, 2019.

[2] A. Micro, "Dasar-dasar Jaringan Komputer (Edisi Revisi 2012," 2012.

[3] R. S. Desmon Sharon, Sapri, "Membangun Jaringan Wireless Local 
Area Network (Wlan) Pada Cv.Biq Bengkulu," J. Media Infotama, vol. 10, no. 1, pp. 35-41, 2014.

[4] G. Sukadarmika, N. I. Er, and N. W. Saputra, "Analisis Coverage WLAN ( Wireless Local Area Netowrk ) 802 . 11a Menggunakan OPNET Modeller," vol. 9, no. 2, 2010.

[5] A. W. Isnanta and M. T. Kurniawan, "Perancangan Jaringan Multiprotocol Label Switching Menggunakan metode NDLC Untuk Layanan VOIP DAN Streaming Video Universitas Telkom," Proceeding Eng., vol. 4, no. 2, pp. 30493056, 2017.

[6] K. Rizki and A. Adil, "Implementasi Google Maps API Berbasis Android untuk Lokasi Fasilitas Umum di Kabupaten Sumbawa," J. MATRIK, vol. 17, no. 2, pp. 34-44, 2018.

[7] T. Zani, "Perancangan High Density Wireless LAN 802.11n 2.4 GHz di Ruang Kelas Fakultas Ilmu Terapan Universitas Telkom," J. Teknol. Inf., vol. 2, no. 3, pp. 103-107, 2017.

[8] F. Imansyah et al., "Analisis simulasi pengaruh uji kuat sinyal wifi dari bahanbahan obstacle 1,2,3)."

[9] M. Tezar and A. Walenta, "Pengembangan Jaringan Infrastruktur Dengan Pengamanan Mikrotik Pada SMA Negeri 1 Pamona Selatan Kabupaten Poso," J. Elektron. Sist. Inf. dan Komput., vol. 2, no. 1, pp. 41-52, 2016.

[10] P. Titahningsih, R. Primananda, and S. R. Akbar, "Perancangan Penempatan Access Point untuk Jaringan Wifi Pada Kereta Api Penumpang," J. Pengemb. Teknol. Inf. dan Ilmu Komput. Univ. Brawijaya, vol. 2, no. 5, pp. 2008-2015, 2018.

[11] M. A. Amanaf, E. S. Nugraha, and D. Kurnianto, "Analisis Simulasi Model COST-231 Multiwall Pathloss Indoor Berbasis Wireless Sensor Network pada Aplikasi Absensi Mahasiswa dengan Tag RFID Menggunakan RPS (Radiowave Propagation Simulator) [Analysis of Wireless Sensor Network-based Indoor COST-231...]," Bul. Pos dan Telekomun., vol. 16, no. 1, p. 17, 2018. 